\title{
Regulated and Unregulated Exhaust Emissions Comparison for Three Tier II Non-Road Diesel Engines Operating on Ethanol- Diesel Blends
}

\author{
Patrick M. Merritt, Vlad Ulmet \\ Southwest Research Institute \\ Robert L. McCormick \\ National Renewable Energy Laboratory \\ William E. Mitchell \\ WM Consulting, Inc. \\ Kirby J. Baumgard \\ John Deere Power Systems
}

\begin{abstract}
Regulated and unregulated emissions (individual hydrocarbons, ethanol, aldehydes and ketones, polynuclear aromatic hydrocarbons $(\mathrm{PAH})$, nitro- $\mathrm{PAH}$, and soluble organic fraction of particulate matter) were characterized in engines utilizing duplicate ISO 8178-C1 eight-mode tests and FTP smoke tests. Certification No. 2 diesel (400 ppm sulfur) and three ethanol/diesel blends, containing 7.7 percent, 10 percent, and 15 percent ethanol, respectively, were used. The three, Tier II, offroad engines were 6.8-L, 8.1-L, and $12.5-\mathrm{L}$ in displacement and each had differing fuel injection system designs. It was found that smoke and particulate matter emissions decreased with increasing ethanol content. Changes to the emissions of carbon monoxide and oxides of nitrogen varied with engine design, with some increases and some decreases. As expected, increasing ethanol concentration led to higher emissions of acetaldehyde (increases ranging from 27 to 139 percent). Benzene emissions were reduced by up to 50 percent with the ethanol-blended fuels. Emissions of 1,3butadiene were also substantially decreased, with reductions ranging from 24 to 82 percent. Isolated trends were noted for certain PAHs. There was a decrease in 1nitropyrene with use of ethanol in all cases. Particulate phase 1-nitropyrene was reduced from 18 to 62 percent. There was also a general increase in the proportion of heavy PAHs in the particulate phase with ethanol use, and although less pronounced, a general decrease in light PAHs in the particulate phase.
\end{abstract}

\section{INTRODUCTION}

Blending of ethanol into diesel fuel may become an important petroleum displacement strategy, if certain technical barriers can be overcome: most importantly, the issues of low flashpoint and tank vapor flammability[1], as well as fuel stability during storage.[2] One source states that blending ethanol into gasoline currently reduces the need to import 128,000 barrels a day of oil into the USA.[3] Other issues, such as durability of engines operating on such fuels, are also important and must be considered. Investigations into lubricity and injector pump wear have been reported using bench test rigs,[4] but discussions of fuel injector and fuel system issues in actual on-engine applications have not been made. It is also important to understand the pollutant emission impacts of blending ethanol into diesel fuel. Prior emissions studies have focused mainly on regulated pollutant emissions while a limited number have included unregulated (mainly carbonyl compound) emissions; for further reading, a review was recently prepared by Corkwell, et. al.[5]

This project involved tests of Tier II compliant, non-road diesel engines to establish the overall impact of dieselethanol blends on regulated engine exhaust emissions, along with a number of unregulated toxic compounds. Four different fuel formulations were used in the engine performance and exhaust emissions evaluations. Three different models of off-road diesel engines were used to assess any effects from differing injection system types, or other mechanical differences. The engines were tested for gaseous emissions and smoke according to EPA Part 89 requirements. In addition to total hydrocarbons, oxides of nitrogen, carbon monoxide, carbon dioxide and 
particulate matter, analyses were performed (on the 8mode tests only) to quantify individual hydrocarbons, aldehydes, ketones, alcohols, polynuclear aromatic hydrocarbons (PAH), 1-nitropyrene, and soluble organic fraction (SOF) of particulate matter.

\section{METHODS}

\section{TEST ENGINES}

John Deere provided three heavy-duty, Tier II compliant, non-road diesel engines for this test program. These engines represent different fuel system and emissions control technologies and varied in displacement from 6.8 to 12.5 liters. The engine characteristics are summarized in Table 1 and include the three most common types of fuel injection systems.

\section{TEST FUELS}

The reference fuel for this program was No. 2D certification diesel, with a nominal sulfur content of 400 ppm. Three different blends of ethanol in this reference fuel were prepared, at $7.7,10$, and 15 percent by volume. Three additive suppliers provided material to enhance the stability and performance of the ethanol in diesel blends. The identity of the additive in a particular fuel blend is confidential, to prevent any use of the data for commercial advantage. For the sake of this program, they are simply designated as "A," "B," and "C." For each of the three ethanol concentrations, a separate blend was prepared utilizing one of each of the three additives. Thus, there resulted a matrix of nine candidate fuels, and one reference fuel. However, only one of each of the three additive blends for each ethanol concentration was run in each engine. Please see Table 2 for matrix of engines and fuels actually tested. The SwRI internal fuel codes are also shown. Each of the three additives was run in one of the engines at each ethanol concentration.

Instructions provided by each additive manufacturer were followed for addition of additive during fuel blending. Additive concentrations (treat rates) varied from 1 to 2.57 percent by volume. Results of analyses of key properties of the ethanol and of the blended fuels are presented in Appendix A. To preclude absorption of water from the atmosphere during storage, a flow of nitrogen in the tank headspace was maintained.

\section{EMISSIONS TEST PROCEDURES}

Exhaust emission characterization was performed as specified under CFR Title 40, Part 89. For non-road heavy-duty engines, the regulation outlines specific requirements for setting up the test engine and pre-test activities, as well as all aspects of conducting the testing and collection and analysis of gaseous samples. The 8mode test cycle was utilized in this test program. Table 3 shows the Part 89 test modes and weighting factors.

Two consecutive runs of the 8-mode test and two FTP smoke tests (40 CFR Parts 86 and 89 ) were performed for each fuel composition. In a regular 8-mode test we stabilize the engine for 5 minutes and sample for 5 minutes. To accumulate a sufficient dilute exhaust sample for unregulated emissions analysis, each mode was run for a number of minutes equivalent to its weight factor in percent (stabilization time of 5 minutes was unchanged). For example, a mode with a 0.10 weight factor received a ten-minute sampling period. This approach extended the total sampling duration for the 8-mode test from 40 to 100 minutes. For the PAH and NPAH sampling, one set of collection media was used to collect a composite sample for each 8-mode test.

TABLE 1. TEST ENGINE CHARACTERISTICS

\begin{tabular}{||l|l|l|l||}
\hline Engine Model & $6081 \mathrm{HRW} 28$ & $6068 \mathrm{HF} 275$ & $6125 \mathrm{HRW} 2$ \\
\hline Displacement, $\mathrm{L}$ & 8.1 & 6.8 & 12.5 \\
\hline Rated Speed, rpm & 2200 & 2000 & 2100 \\
\hline Rated Power, $\mathrm{kW}(\mathrm{hp})$ & $224(301)$ & $129(172)$ & $375(500)$ \\
\hline Intermediate Speed, rpm & 1400 & 1400 & 1500 \\
\hline Peak Torque, $\mathrm{N}-\mathrm{m}(\mathrm{lb}-\mathrm{ft})$ & $1361(1004)$ & $725(535)$ & $1989(1467)$ \\
\hline Inlet Restriction, $\mathrm{kPa}$ (in. water) & $2.99(12)$ & $2.99(12)$ & $2.99(12)$ \\
\hline Exhaust Restriction, $\mathrm{kPa}$ (in. mercury) & $7.45(2.2)$ & $7.45(2.2)$ & $7.45(2.2)$ \\
\hline Turbocharged/Inter-cooled & Yes/Yes & Yes/Yes & Yes/Yes \\
\hline Inter-cooling type & Air/Air & Air/Air & Air/Air \\
\hline Inter-cooler Outlet Temperature, ${ }^{\circ} \mathrm{C}\left({ }^{\circ} \mathrm{F}\right)$ & $60(140)$ & $60(140)$ & $60(140)$ \\
\hline Inter-cooler $\Delta \mathrm{P}, \mathrm{kPa}$ (in. water) & $12.45(50)$ & $12.45(50)$ & $12.45(50)$ \\
\hline Fuel System & $\begin{array}{l}\text { High pressure, } \\
\text { common rail }\end{array}$ & $\begin{array}{l}\text { Rotary pump line } \\
\text { nozzle }\end{array}$ & Electronic unit injector \\
\hline
\end{tabular}


TABLE 2. TEST FUEL MATRIX

\begin{tabular}{|c|c|c|c|c|c|}
\hline Engine ID & Additive & Cert. Fuel & $7.7 \%$ Blend & $10 \%$ Blend & $15 \%$ Blend \\
\hline \multirow{4}{*}{ John Deere 8.1-L } & NONE & EM-4970-F & & & \\
\hline & A & & EM-4929-F & & \\
\hline & $B$ & & & EM-4936-F & \\
\hline & C & & & & EM-4951-F \\
\hline \multirow{4}{*}{ John Deere 6.8-L } & NONE & EM-4970-F & & & \\
\hline & $A$ & & & & EM-4949-F \\
\hline & $B$ & & EM-4930-F & & \\
\hline & $\mathrm{C}$ & & & EM-4937-F & \\
\hline \multirow{4}{*}{ John Deere 12.5-L } & NONE & EM-4970-F & & & \\
\hline & A & & & EM-4935-F & \\
\hline & $B$ & & & & EM-4950-F \\
\hline & $\mathrm{C}$ & & EM-4932-F & & \\
\hline
\end{tabular}

TABLE 3. PART 89 TEST MODES AND WEIGHTING FACTORS

\begin{tabular}{|c|c|c|c|c|c|c|c|c|}
\hline Mode & 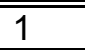 & 2 & 3 & 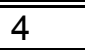 & 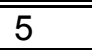 & $\overline{6}$ & $\overline{77}$ & 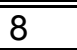 \\
\hline Speed & \multicolumn{4}{|c|}{ Rated } & \multicolumn{3}{|c|}{ Intermediate } & Idle \\
\hline Percent Torque & 100 & 75 & 50 & 10 & 100 & 75 & 50 & 0 \\
\hline Weight Factor & 0.15 & 0.15 & 0.15 & 0.10 & 0.10 & 0.10 & 0.10 & 0.15 \\
\hline
\end{tabular}

\section{EMISSIONS SAMPLING AND ANALYSIS PROCEDURES - REGULATED EMISSIONS}

Regulated emissions determined on the 8-mode test included total hydrocarbon ( $\mathrm{HC})$, carbon monoxide (CO), oxides of nitrogen (NOx), carbon dioxide (CO2), and total particulate matter (PM). These emissions were collected and analyzed utilizing procedures that conform to the requirements stated in 40 CFR Part 89.

\section{EMISSIONS SAMPLING AND ANALYSIS PROCEDURES - UNREGULATED EMISSIONS}

The target list for unregulated emissions included the soluble organic fraction of the PM (SOF), aldehydes and ketones (ALD), ethanol (ETH), individual hydrocarbons $(\mathrm{IHC})$, polycyclic aromatic hydrocarbons (PAH), and 1nitropyrene. For each mode, SOF was determined by extracting a 50 percent section of the particulate-laden $90 \mathrm{~mm}$ Pallflex filters using a Soxhlet apparatus with toluene-ethanol solvent. Solvent is evaporated from the extracted particulate filters and the filters are re-weighed. The difference in mass is the solvent-extractable material.

Individual hydrocarbons were measured from proportional bag samples of dilute exhaust for each mode using gas chromatography. Compounds ranging from $\mathrm{C} 1$ to $\mathrm{C} 12$, are identified and quantified in a process that requires four separate chromatographs. The process is based on the Auto/Oil Phase II Hydrocarbon Speciation procedure.[6] Full hydrocarbon speciation includes analysis of aldehydes, ketones, and alcohols if oxygenates are present in the fuel. Currently, EPA has identified four compounds that it has classified as "toxic."[7] Those compounds are benzene, 1,3-butadiene, formaldehyde, and acetaldehyde.

Aldehydes and ketones (collectively known as carbonyl compounds) were sampled from the dilute exhaust for each mode utilizing impingers containing a solution of dinitrophenylhydrazine (DNPH) in acetonitrile. The highly reactive carbonyl compounds form stable derivatives with DNPH, which absorb ultra-violet light energy at specific wavelengths. These samples were analyzed using a high-pressure liquid chromatograph (HPLC) instrument using a ternary eluent gradient program (acetonitrilewater-methanol) with an ultraviolet detector.

Ethanol samples were collected for each mode utilizing impingers containing pure water. An aliquot was subsequently analyzed using gas chromatography with flame ionization detection (GC-FID).

The PAH and 1-nitropyrene are distributed in both the particulate and the gaseous phase of the dilute exhaust, and are difficult to measure at low concentrations. Additionally, there was concern that the sampling system has a "memory" for some PAH; therefore, additional effort to condition the sampling system with exhaust from the fuel under test was desirable. To accommodate these concerns, only after routing exhaust from several practice runs and preparatory operations through the constant volume sampler (CVS), was dilute engine exhaust sampling performed for record, using one composite sample for the entire 8-mode test. The composite sample approach increased the level of complexity of the sampling system but gave an almost eightfold analytical sensitivity and analysis cost benefit. During each five- 
minute engine stabilization period at the beginning of each mode prior to emission sampling, the dilute exhaust sample flow going to the PAH samples was diverted, in order to protect the integrity of the 8-mode sample.

The dilute exhaust sampling process for $\mathrm{PAH}$ is described as follows. For the particulate-phase sampling, a single 20x20-inch Pallflex filter was used to collect particulatephase $\mathrm{PAH}$ for the whole duration of each 8-mode test. Another filter was then used for the "blank" sampling, during which only the dilution tunnel was turned on (no engine operation). It was operated for the same duration as the entire 8-mode test.

Similarly, for the gas-phase $\mathrm{PAH}$ collection, a set of four PUF/XAD-2 traps was run in parallel over the full, 8-mode sequence to accumulate gas-phase $\mathrm{PAH}$ compounds. Four parallel traps were required to give sufficient gas flow (sample size) for meaningful detection limits. The PUF/XAD-2 trap set was extracted to generate a separate sample for the gas-phase $\mathrm{PAH}$ analysis.

Only the samples from one of each duplicate, 8-mode test (particulate- and gas-phase) were processed for final analysis of the PAH emissions. The samples from the second 8-mode test were extracted and stored as a backup. Subsequent to each 8-mode test, a "blank" sample, using a period of time similar to that used to accumulate dilute exhaust samples, was taken.

Following sample cleanup and derivativization, the extracts were analyzed by gas chromatography / mass spectrometry (GC/MS). The GC/MS system used included an Agilent 6890N GC equipped with a G2613A Automatic Sampler and interfaced to an Agilent 5973N MS detector. Injections $(1 \mu \mathrm{L})$ were made in the splitless mode onto a $60 \mathrm{~m} \mathrm{5 \%}$ phenylmethylsilicone fused-silica capillary column (DB- $5 \mathrm{~ms}$, J\&W Scientific). Analysis of the PAH compounds was performed by GC/MS in positive ion/electron impact/selective ion monitoring (PI/EI/SIM) mode. The molecular ion or characteristic ion of each compound of interest and deuterated $\mathrm{PAH}$, added as internal standards prior to extraction, were monitored. The NPAH and deuterated NPAH (internal standards) were quantified using the same GC/MS described above. However, the GC/MS was operated in negative ion/chemical ionization/SIM (NI/CI/SIM) mode. This technique is proven to be much more sensitive for the $\mathrm{N}$ $\mathrm{PAH}$ 's than using $\mathrm{PI} / \mathrm{EI} / \mathrm{SIM}$ technique.

\section{RESULTS}

\section{1-Liter Engine Results}

A summary of averaged, composite values for the duplicate, 8-mode tests of the 8.1-L engine operating on each fuel are presented in Table 4 and in Figure 1. (Note that $\mathrm{NO}_{\mathrm{x}}$ is divided by ten to use the same scale.)

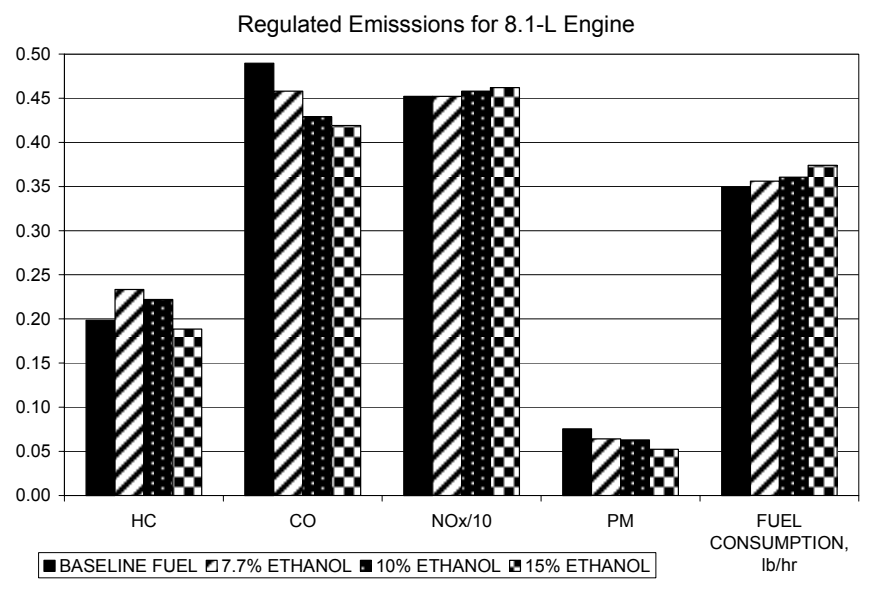

Figure 1. Regulated Emissions and Fuel Consumption for 8.1-L Engine

Carbon balance fuel consumption (C-B FC) is computed from the emissions data, while observed fuel consumption (OBS. FC) is derived from integrated measurement of flow and calculated work. Both are weighted average brake specific expressions. These values generally agree closely.

Emissions of hydrocarbons generally increased with the ethanol blends. The highest result, however, was observed with the 7.7 percent blend and dropped off with increasing ethanol content, to being slightly less than the baseline result for the 15 percent blend. Carbon monoxide and particulate emissions showed a definite reduction in line with increasing ethanol content. Emissions of $\mathrm{NO}_{x}$ increased slightly as ethanol content increased.

\section{TABLE 4. REGULATED EMISSIONS SUMMARY FOR 8.1-LITER ENGINE AVERAGED, COMPOSITE RESULTS OVER 8-MODE TEST}

\begin{tabular}{|l|c|c|c|c|c||}
\hline \multicolumn{1}{|c|}{ FUEL TYPE } & BASELINE FUEL & 7.7\% ETHANOL & 10\% ETHANOL & 15\% ETHANOL & BASELINE FUEL \\
\hline \hline $\mathrm{HC}, \mathrm{g} / \mathrm{bhp}-\mathrm{hr}$ & 0.195 & 0.235 & 0.220 & 0.190 & 0.196 \\
\hline $\mathrm{CO}, \mathrm{g} / \mathrm{bhp}-\mathrm{hr}$ & 0.490 & 0.460 & 0.430 & 0.420 & 0.491 \\
\hline $\mathrm{NO}, \mathrm{g} / \mathrm{bhp}-\mathrm{hr}$ & 4.52 & 4.52 & 4.58 & 4.62 & 4.43 \\
\hline Particulate, g/bhp-hr & 0.076 & 0.064 & 0.063 & 0.053 & 0.082 \\
\hline CO2, g/bhp-hr & 503 & 497 & 501 & 503 & 501 \\
\hline C-B FC, lb/bhp-hr & 0.35 & 0.36 & 0.36 & 0.37 & 0.35 \\
\hline OBS. FC, lb/bhp-hr & 0.34 & 0.35 & 0.35 & 0.37 & 0.35 \\
\hline
\end{tabular}




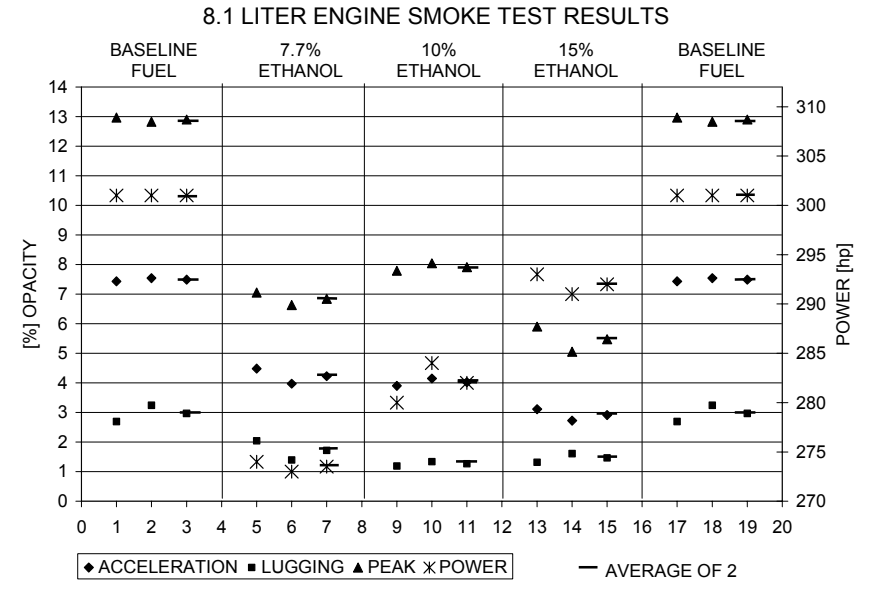

Figure 2. Smoke Test Results for 8.1-L Engine

Smoke test results are presented in Figure 2. Results indicated a reduction in opacity trending with increasing ethanol content under acceleration, lugging, and peak modes. This figure also captures the lower power levels measured with the different ethanol concentrations.

Soluble organic fraction of particulate matter is summarized in Table 5 . SOF tended to increase with ethanol content as compared to baseline diesel fuel. SOF levels were, as expected, highest for the low load modes 4 and 8 . Mode 7 exhibited the largest difference in SOF between baseline diesel fuel and an ethanol blend (in this case the $15 \%$ blend).

Individual hydrocarbon emissions results are summarized in Table 6. Increase emissions of formaldehyde, acetaldehyde, and ethanol were observed with increasing ethanol content. Emissions of 1,3-butadiene and benzene were reduced slightly with the ethanol blends.
PAH and NPAH results presented in Table 7. Please note that PAH and NPAH compounds are expressed in nanograms $\left(10^{-9} \mathrm{~g}\right)$. In the vapor phase, acenaphthylene and fluorene are lower for the alcohol blends, but fluoranthene and pyrene are higher. An increasing trend with alcohol content is observable for benzo(a)anthracene and chrysene in this view. For the lighter molecular weight compounds in the particulate-phase, all compounds are lower in the ethanol blends than in the baseline diesel. For the heavier molecular weight compounds in the particulate-phase, benzo(b)fluoranthene, benzo(k)fluoranthene, benzo(a)pyrene, indeno(1,2,3-cd)pyrene, and dibenzo(a,h)anthracene are all higher for the ethanol blends, but 1-nitropyrene is lower.

\section{TABLE 5. SOLUBLE ORGANIC FRACTION BY MODE FOR 8.1-L-ENGINE PERCENT OF TOTAL PARTICULATE MATTER}

\begin{tabular}{||l|c|c|c|c||}
\hline Fuel Type & $\begin{array}{c}\text { Baseline } \\
\text { Average }\end{array}$ & $\begin{array}{c}\mathbf{7 . 7 \%} \\
\text { Ethanol }\end{array}$ & $\begin{array}{c}\mathbf{1 0 \%} \\
\text { Ethanol }\end{array}$ & $\begin{array}{c}\mathbf{1 5 \%} \\
\text { Ethanol }\end{array}$ \\
\hline \multicolumn{5}{|||}{ Soluble Organic Fraction, percent of total particulate } \\
\hline Mode 1 & 40.5 & 56.3 & 58.2 & 58.0 \\
\hline Mode 2 & 35.9 & 48.8 & 41.4 & 48.6 \\
\hline Mode 3 & 38.2 & 40.2 & 39.4 & 39.0 \\
\hline Mode 4 & 88.4 & 88.0 & 87.6 & 93.0 \\
\hline Mode 5 & 33.6 & 39.7 & 37.1 & 45.1 \\
\hline Mode 6 & 30.8 & 44.1 & 38.4 & 49.5 \\
\hline Mode 7 & 46.7 & 66.5 & 48.8 & 67.7 \\
\hline Mode 8 & 87.9 & 93.6 & 82.9 & 90.0 \\
\hline
\end{tabular}

TABLE 6. UNREGULATED EMISSIONS SUMMARY FOR 8.1-LITER ENGINE AVERAGED, COMPOSITE RESULTS OVER 8-MODE TEST, $\mathrm{mg} / \mathrm{hp}$-hr

\begin{tabular}{|l|c|c|c|c|}
\hline \multicolumn{1}{|c|}{ FUEL TYPE } & BASELINE FUEL & $7.7 \%$ ETHANOL & $10 \%$ ETHANOL & $15 \%$ ETHANOL \\
\hline \hline FORMALDEHYDE & 9.56 & 10.21 & 10.52 & 11.00 \\
\hline ACETALDEHYDE & 3.70 & 4.71 & 4.68 & 5.51 \\
\hline ACROLEIN & 1.87 & 1.83 & 1.43 & 1.59 \\
\hline PROPIONALDEHYDE & 0.68 & 0.83 & 1.18 & 1.22 \\
\hline METHYL ETHYL KETONE & 0.53 & 0.59 & 0.09 & 0.09 \\
\hline ETHANOL & 0.32 & 16.58 & 17.65 & 0.69 \\
\hline 1,3-BUTADIENE & 0.90 & 0.92 & 0.68 & 0.15 \\
\hline METHANE & 2.09 & 0.32 & 0.53 & 0.72 \\
\hline BENZENE & 0.81 & 0.70 & 0.69 & 1.17 \\
\hline TOLUENE & 1.00 & 1.61 & 0.90 & 0.55 \\
\hline ETHYLBENZENE & 0.51 & 0.53 & 0.42 & 0.89 \\
\hline m-\& P-XYLENE & 0.85 & 0.74 & 0.61 & 0.16 \\
\hline o-XYLENE & 0.39 & 0.34 & 0.38 & 0.10 \\
\hline HEXANE & 0.03 & 0.11 & 0.07 & 0.11 \\
\hline STYRENE & 0.12 & 0.07 & & \\
\hline
\end{tabular}


TABLE 7. PAH and NPAH COMPOUNDS FOR 8.1-L ENGINE, COMPOSITE RESULTS OVER 8-MODE TEST, ng/hp-hr

\begin{tabular}{|l|c|c|c|c|c|c|c|c||}
\hline \multicolumn{1}{|c|}{ FUEL TYPE } & \multicolumn{2}{c|}{ BASELINE FUEL } & \multicolumn{2}{c|}{$7.7 \%$ ETHANOL } & \multicolumn{2}{c|}{$10 \%$ ETHANOL } & \multicolumn{2}{c||}{$15 \%$ ETHANOL } \\
\hline COMPOUND/PHASE & $\begin{array}{c}\text { VAPOR } \\
\text { PHASE }\end{array}$ & PM PHASE & $\begin{array}{c}\text { VAPOR } \\
\text { PHASE }\end{array}$ & PM PHASE & $\begin{array}{c}\text { VAPOR } \\
\text { PHASE }\end{array}$ & PM PHASE & $\begin{array}{c}\text { VAPOR } \\
\text { PHASE }\end{array}$ & PM PHASE \\
\hline \hline Naphthalene & 224515 & 237 & 234480 & 84 & 472781 & 144 & 219800 & 95 \\
\hline Acenaphthylene & 1244 & 146 & 271 & 72 & 277 & 97 & 49 & 62 \\
\hline Acenaphthene & 30207 & 89 & 30172 & 51 & 35886 & 63 & 30678 & 41 \\
\hline Fluorene & 59566 & 471 & 47348 & 207 & 56904 & 295 & 45485 & 162 \\
\hline Phenanthrene & 99538 & 7419 & 91207 & 3428 & 103191 & 4084 & 76198 & 2244 \\
\hline Anthracene & 6519 & 710 & 6443 & 331 & 6842 & 368 & 5123 & 208 \\
\hline Fluoranthene & 2274 & 2390 & 2935 & 348 & 3266 & 1627 & 2657 & 919 \\
\hline Pyrene & 3674 & 5146 & 6413 & 3741 & 6267 & 3959 & 5685 & 2493 \\
\hline Benzo(a)anthracene & 7 & 358 & 16 & 428 & 13 & 403 & 17 & 275 \\
\hline Chrysene & 16 & 834 & 30 & 830 & 30 & 877 & 35 & 617 \\
\hline Benzo(b)fluoranthene & 2 & 145 & 1 & 179 & 2 & 183 & 1 & 160 \\
\hline Benzo(k)fluoranthene & 2 & 84 & 1 & 155 & 1 & 126 & 0 & 125 \\
\hline Benzo(a)pyrene & 1 & 87 & 0 & 171 & 1 & 136 & 0 & 111 \\
\hline Indeno(1,2,3-cd)pyrene & 1 & 14 & 1 & 27 & 1 & 32 & 1 & 34 \\
\hline Dibenzo(a,h)anthracene & 2 & 5 & 0 & 8 & 0 & 10 & 0 & 8 \\
\hline 1-Nitropyrene & 0 & 129 & 1 & 68 & 1 & 90 & 2 & 79 \\
\hline
\end{tabular}

\section{8-LITER ENGINE RESULTS}

A summary of averaged, composite values for the duplicate, 8-mode tests of the 6.8-L engine operating on each fuel are presented in Table 8 and in Figure 3. For the 6.8-L engine, there was no observable trend for hydrocarbon emissions. Carbon monoxide emissions increased with increasing ethanol content, and particulate emissions showed the opposite trend. Emissions of oxides of nitrogen were reduced with the ethanol-blended fuels, but were relatively constant regardless of ethanol content.

Smoke test results are presented in Figure 4 and soluble organic fraction of particulate matter is summarized in Table 9. For the 6.8-L engine, smoke opacity was reduced in proportion to ethanol content for all operational modes. SOF was highest for modes 4 and 8 and in general was higher with increasing ethanol content. Results for modes 1 and 8 did not follow this trend, however, where SOF was reduced with the ethanol blended fuels.

Significant increases were observed in emissions of acetaldehyde (and of ethanol) with increasing ethanol content. Emissions of 1,3-butadiene were reduced with ethanol blends, but benzene emissions were not significantly affected. Individual hydrocarbon emissions results are summarized in Table 10.

$\mathrm{PAH}$ results presented in Table 11. For the lighter molecular weight compounds for the vapor phase only, phenanthrene is lower for the alcohol blends, but fluoranthene and pyrene are higher. For the lighter molecular weight compounds in the particulate phase only most compounds are lower in the ethanol blends. In the heavier molecular weight compounds for the particulate phase, all compounds except 1-nitropyrene are higher in the ethanol blends. Lower emission rates are seen for 1nitropyrene with the ethanol blends.

TABLE 8. REGULATED EMISSIONS SUMMARY FOR 6.8-LITER ENGINE AVERAGED, COMPOSITE RESULTS OVER 8-MODE TEST

\begin{tabular}{||l|c|c|c|c|c||}
\hline FUEL TYPE & BASELINE FUEL & $7.7 \%$ ETHANOL & $10 \%$ ETHANOL & $15 \%$ ETHANOL & BASELINE FUEL \\
\hline \hline $\mathrm{HC}, \mathrm{g} / \mathrm{bhp}-\mathrm{hr}$ & 0.35 & 0.34 & 0.34 & 0.38 & 0.33 \\
\hline $\mathrm{CO}, \mathrm{g} / \mathrm{bhp}-\mathrm{hr}$ & 0.62 & 0.64 & 0.68 & 0.76 & 0.60 \\
\hline $\mathrm{NO}_{\mathrm{x}}, \mathrm{g} / \mathrm{bhp}-\mathrm{hr}$ & 3.95 & 3.60 & 3.59 & 3.62 & 3.84 \\
\hline Particulate, g/bhp-hr & 0.159 & 0.153 & 0.145 & 0.124 & 0.169 \\
\hline $\mathrm{CO} 2, \mathrm{~g} / \mathrm{bhp}-\mathrm{hr}$ & 526 & 518 & 526 & 522 & 516 \\
\hline C-B FC, lb/bhp-hr & 0.37 & 0.37 & 0.38 & 0.38 & 0.38 \\
\hline OBS. FC, lb/bhp-hr & 0.35 & 0.36 & 0.36 & 0.36 & 0.34 \\
\hline
\end{tabular}




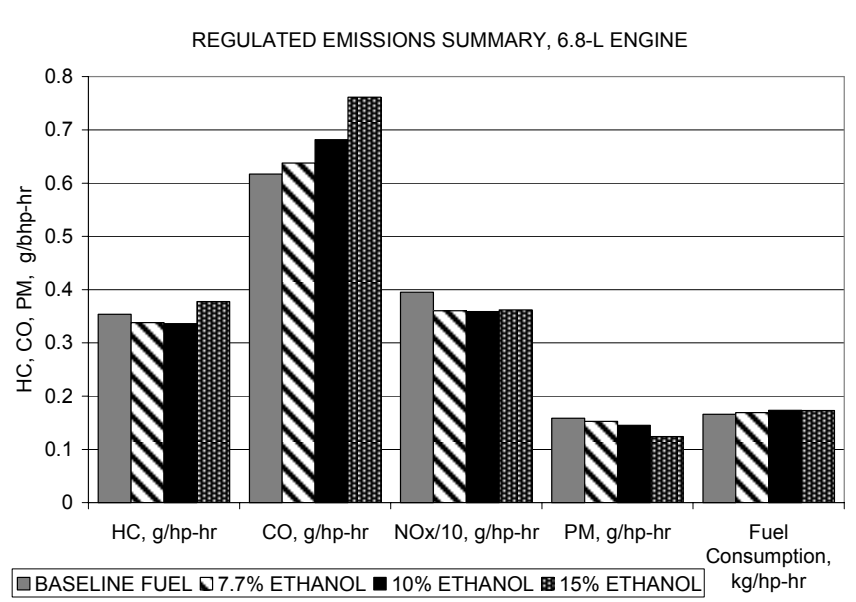

Figure 3. Regulated Emission Summary and Fuel Consumption for 6.8-L Engine

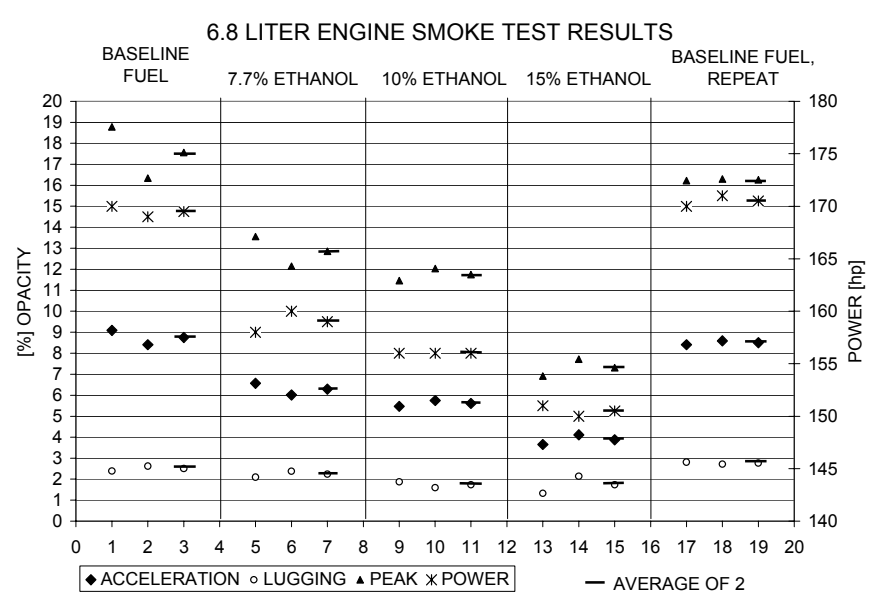

Figure 4. Smoke Test Results For 6.8-L Engine

TABLE 9. SOLUBLE ORGANIC FRACTION BY MODE FOR 6.8-L ENGINE, PERCENT OF TOTAL PARTICULATE MATTER

\begin{tabular}{|l|c|c|c|c|c|c|c|c||}
\hline Fuel Type & \multicolumn{2}{|c|}{ BASELINE FUEL } & \multicolumn{2}{c|}{$7.7 \%$ ETHANOL } & \multicolumn{2}{c|}{$10 \%$ ETHANOL } & \multicolumn{2}{c|}{ 15\% ETHANOL } \\
\hline Replicate & Test 1 & Test 2 & Test 1 & Test 2 & Test 1 & Test 2 & Test 1 & Test 2 \\
\hline Mode 1 & 12.8 & 16.6 & 11.4 & 12.7 & 11.7 & 13.8 & 15.3 & 12.4 \\
\hline Mode 2 & 22.1 & 21.4 & 26.6 & 23.5 & 19.5 & 26.5 & 36.3 & 33.0 \\
\hline Mode 3 & 50.1 & 48.9 & 53.9 & 66.0 & 49.6 & 61.8 & 73.8 & 63.0 \\
\hline Mode 4 & 78.9 & 83.5 & 84.8 & 80.4 & 75.8 & 84.3 & 83.4 & 88.5 \\
\hline Mode 5 & 6.8 & 11.7 & 10.9 & 9.3 & 8.5 & 11.8 & 14.7 & 14.4 \\
\hline Mode 6 & 28.7 & 21.8 & 26.5 & 22.2 & 29.9 & 27.2 & 34.1 & 33.2 \\
\hline Mode 7 & 46.5 & 48.8 & 60.5 & 48.4 & 58.7 & 60.1 & 58.3 & 62.2 \\
\hline Mode 8 & 91.4 & 85.9 & 61.3 & 75.2 & 92.8 & 88.2 & 67.9 & $>99.0$ \\
\hline
\end{tabular}

TABLE 10. UNREGULATED EMISSIONS SUMMARY FOR 6.8-LITER ENGINE AVERAGED, COMPOSITE RESULTS OVER 8-MODE TEST, mg/hp-hr

\begin{tabular}{||l|c|c|c|c||}
\hline COMPOUND/FUEL TYPE & BASELINE FUEL & $7.7 \%$ ETHANOL & $10 \%$ ETHANOL & $15 \%$ ETHANOL \\
\hline \hline FORMALDEHYDE & 16.56 & 14.77 & 14.88 & 20.11 \\
\hline ACETALDEHYDE & 4.82 & 6.27 & 7.56 & 10.82 \\
\hline ACROLEIN & 2.04 & 0.47 & 0.75 & 2.68 \\
\hline PROPIONALDEHYDE & 2.35 & 1.32 & 1.39 & 1.81 \\
\hline METHYL ETHYL KETONE & 0.15 & 0.13 & 0.30 & 0.16 \\
\hline ETHANOL & 0.44 & 23.22 & 32.82 & 52.66 \\
\hline 1,3-BUTADIENE & 1.70 & 1.40 & 0.56 & 1.03 \\
\hline METHANE & 0.71 & 1.14 & 2.37 & 3.11 \\
\hline BENZENE & 1.78 & 1.68 & 1.79 & 1.82 \\
\hline TOLUENE & 3.05 & 0.84 & 1.80 & 1.83 \\
\hline ETHYLBENZENE & 0.90 & 0.68 & 0.51 & 0.76 \\
\hline m- $\&$ p-XYLENE & 1.36 & 0.97 & 0.95 & 2.08 \\
\hline o-XYLENE & 0.63 & 0.50 & 0.60 & 1.50 \\
\hline HEXANE & 0.11 & 0.26 & 0.36 & 0.48 \\
\hline STYRENE & 0.26 & 0.18 & 0.11 & 0.19 \\
\hline \hline
\end{tabular}



TABLE 11. PAH and NPAH COMPOUNDS FOR 6.8-L ENGINE,
COMPOSITE RESULTS OVER 8-MODE TEST, ng/HP-HR

\begin{tabular}{|l|c|c|c|c|c|c|c|c||}
\hline \multirow{2}{*}{ FUEL TYPE } & \multicolumn{2}{|c|}{ BASELINE FUEL } & \multicolumn{2}{c|}{$7.7 \%$ ETHANOL } & \multicolumn{2}{c|}{$10 \%$ ETHANOL } & \multicolumn{2}{c||}{$15 \%$ ETHANOL } \\
\hline COMPOUND/PHASE & $\begin{array}{c}\text { VAPOR } \\
\text { PHASE }\end{array}$ & $\begin{array}{c}\text { PM } \\
\text { PHASE }\end{array}$ & $\begin{array}{c}\text { VAPOR } \\
\text { PHASE }\end{array}$ & $\begin{array}{c}\text { PM } \\
\text { PHASE }\end{array}$ & $\begin{array}{c}\text { VAPOR } \\
\text { PHASE }\end{array}$ & $\begin{array}{c}\text { PM } \\
\text { PHASE }\end{array}$ & $\begin{array}{c}\text { VAPOR } \\
\text { PHASE }\end{array}$ & $\begin{array}{c}\text { PM } \\
\text { PHASE }\end{array}$ \\
\hline \hline Naphthalene & 390119 & 408 & 108331 & 371 & 245566 & 299 & 381781 & 161 \\
\hline Acenaphthylene & 34922 & 154 & 16425 & 162 & 36284 & 117 & 40979 & 95 \\
\hline Acenaphthene & 34574 & 163 & 21906 & 114 & 53332 & 95 & 33762 & 46 \\
\hline Fluorene & 64597 & 335 & 48300 & 323 & 65698 & 248 & 54219 & 324 \\
\hline Phenanthrene & 147670 & 11876 & 75958 & 9180 & 102103 & 8572 & 75822 & 5694 \\
\hline Anthracene & 9506 & 1374 & 4698 & 1128 & 6717 & 1011 & 9531 & 613 \\
\hline Fluoranthene & 1735 & 4467 & 1950 & 4988 & 2281 & 4481 & 5203 & 2984 \\
\hline Pyrene & 1591 & 8429 & 2567 & 12128 & 4212 & 12127 & 8128 & 6239 \\
\hline Benzo(a)anthracene & 5 & 365 & 0 & 487 & 0 & 456 & 2 & 545 \\
\hline Chrysene & 7 & 1243 & 8 & 1307 & 6 & 1263 & 7 & 1513 \\
\hline Benzo(b)fluoranthene & 0 & 77 & 0 & 117 & 0 & 103 & 0 & 233 \\
\hline Benzo(k)fluoranthene & 0 & 105 & 0 & 117 & 0 & 119 & 0 & 174 \\
\hline Benzo(a)pyrene & 0 & 39 & 0 & 94 & 0 & 81 & 0 & 151 \\
\hline Indeno(1,2,3-cd)pyrene & 0 & 10 & 0 & 11 & 0 & 10 & 0 & 27 \\
\hline Dibenzo(a,h)anthracene & 0 & 4 & 0 & 6 & 0 & 6 & 0 & 12 \\
\hline 1-Nitropyrene & 0 & 276 & 0 & 105 & 2 & 118 & 0 & 103 \\
\hline \hline
\end{tabular}

\section{5-LITER ENGINE RESULTS}

Power output of the 12.5-I engine was consistent with the manufacturer's ratings when operating on straight diesel fuel, but problems were experienced when first operating with ethanol-blended fuel. After a period of operation on ethanol-blended fuel, the power output would drop-off and become erratic. It was determined that the performance problems were caused by the ethanol-blended fuel boiling while in the fuel system. The fuel is routed through the head on this engine design, as is common practice with unit injection. In addition, a portion of the unused fuel is re-circulated through the head, rather than being returned to the fuel tank. It is likely that the fuel became too hot and began to boil while passing through the head. To remedy the situation, a small cooler was installed to reduce the fuel temperature prior to reaching the injectors. After this modification was installed, the engine performed well, and testing proceeded.

A summary of averaged, composite values for the duplicate, 8-mode tests of the 12.5-L engine operating on each fuel are presented in Table 12 and Figure 5. Emissions of $\mathrm{NO}_{x}$, particulate, and $\mathrm{CO}$ were reduced with the ethanol blended fuels. $\mathrm{HC}$ emissions increased with ethanol content.

Smoke test results are presented in Figure 6. Smoke opacity was reduced with increasing ethanol content in all cases. Results are shown for the 7.7 percent blend without the fuel temperature control discussed above. Results are shown for the 10 percent blend with and without temperature control, and with temperature control for the 15 percent blend.

Soluble organic fraction of particulate matter is summarized in Table 13. SOF showed consistent increases with ethanol content in modes 2 and 4 . SOF was highest in mode 8 . In mode 8 , there was little difference in SOF for the four fuels.

Individual hydrocarbon emissions results are summarized in Table 14. As expected, emissions of acetaldehyde and ethanol increased with increasing ethanol content. Other aldehydes tended to increase as well. Benzene and 1,3butadiene increased with increasing ethanol content, but were all lower than base fuel.

PAH and NPAH results are presented in Table 15. For the lighter molecular weight compounds in the vapor phase, an increasing trend for pyrene is observed, and naphthalene, acenaphthene, fluoranthene are higher in the ethanol blends. Acenaphthylene and acenaphthene are lower in the ethanol blends. For the heavier molecular weight compounds for the vapor phase, benzo(a)anthracene and chrysene show a definite increasing trend with ethanol concentration. Benzo(a)pyrene was higher in the ethanol blends. However, 1-nitropyrene was lower in the ethanol blends. In the particulate-phase decreasing trends for acenaphthylene, fluorene, phenanthrene, anthracene, fluoranthene, and pyrene are seen with increasing ethanol content. The heavier compounds are higher for the ethanol blends in the particulate phase, but 1-nitropyrene is lower. 
TABLE 12. REGULATED EMISSIONS SUMMARY FOR 12.5-LITER ENGINE AVERAGED, COMPOSITE RESULTS

\begin{tabular}{|l|c|c|c|c|c||}
\hline FUEL TYPE & BASELINE FUEL & $7.7 \%$ ETHANOL & \multirow{2}{*}{$10 \%$ ETHANOL } & 15\% ETHANOL & BASELINE FUEL \\
\hline \hline HC, g/bhp-hr & 0.215 & 0.245 & 0.260 & 0.255 & 0.210 \\
\hline CO, g/bhp-hr & 0.420 & 0.355 & 0.355 & 0.360 & 0.430 \\
\hline NO, g/bhp-hr & 4.03 & 3.86 & 3.81 & 3.83 & 4.03 \\
\hline Particulate, g/bhp-hr & 0.085 & 0.074 & 0.072 & 0.069 & 0.091 \\
\hline CO2, g/bhp-hr & 491 & 495 & 494 & 492 & 495 \\
\hline C-B FC, lb/bhp-hr & 0.34 & 0.35 & 0.35 & 0.36 & 0.34 \\
\hline OBS. F-C, lb/bhp-hr & 0.34 & 0.34 & 0.34 & 0.35 & 0.33 \\
\hline
\end{tabular}

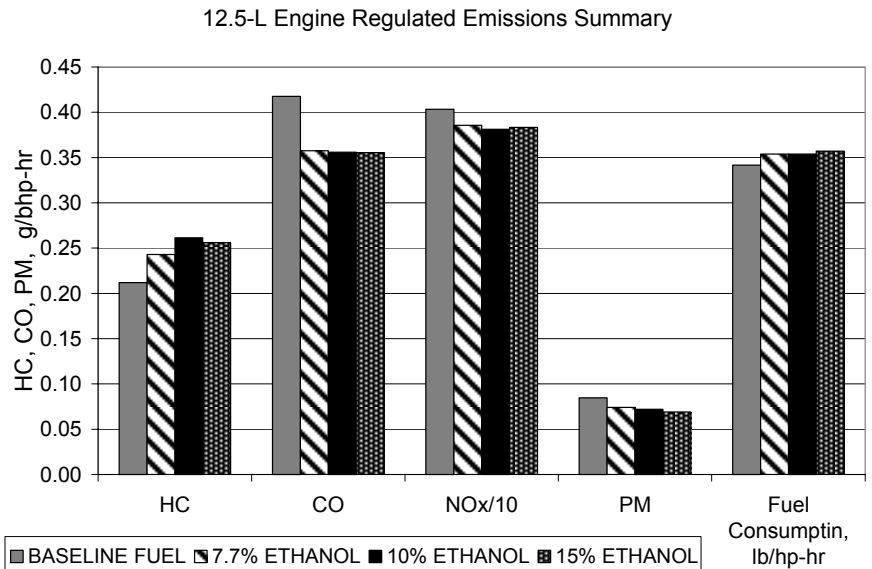

Figure 5. Regulated Emissions Summary, 12.5-L Engine

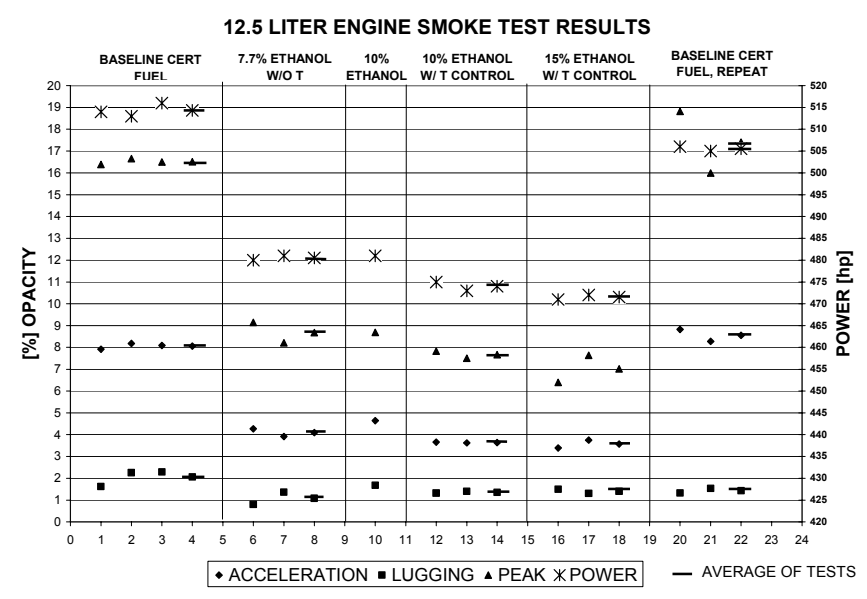

Figure 6. Smoke Test Results For 12.5-L Engine

TABLE 13. SOLUBLE ORGANIC FRACTION BY MODE FOR 12.5-L ENGINE, PERCENT OF TOTAL PARTICULATE MATTER

\begin{tabular}{|l|c|c|c|c|c|c|c|c||}
\hline Fuel Type & \multicolumn{2}{|c|}{ BASELINE FUEL } & \multicolumn{2}{c|}{$7.7 \%$ ETHANOL } & \multicolumn{2}{c|}{$10 \%$ ETHANOL } & \multicolumn{2}{c||}{ 15\% ETHANOL } \\
\hline Replicate & Test 1 & Test 2 & Test 1 & Test 2 & Test 1 & Test 2 & Test 1 & Test 2 \\
\hline \hline Mode 1 & 63.2 & 51.8 & 54.8 & 63.2 & 65.7 & 52.0 & 65.3 & 65.8 \\
\hline Mode 2 & 49.1 & 41.1 & 59.7 & 49.1 & 55.6 & 58.7 & 67.5 & 61.4 \\
\hline Mode 3 & 40.9 & 36.9 & 44.9 & 40.9 & 40.7 & 44.6 & 44.9 & 37.9 \\
\hline Mode 4 & 44.4 & 32.0 & 44.6 & 44.4 & 42.0 & 42.2 & 49.7 & 47.8 \\
\hline Mode 5 & 74.6 & 68.0 & 67.7 & 74.6 & 65.6 & 68.8 & 85.4 & 62.0 \\
\hline Mode 6 & 80.1 & 58.0 & 82.2 & 80.1 & 70.3 & 73.5 & 100 & 69.2 \\
\hline Mode 7 & 63.2 & 65.7 & 72.4 & 63.2 & 69.0 & 56.7 & 56.4 & 62.4 \\
\hline Mode 8 & 100 & 100 & 100 & 100 & 100 & 100 & 100 & 98.0 \\
\hline
\end{tabular}


TABLE 14. UNREGULATED EMISSIONS SUMMARY FOR 12.5-LITER ENGINE AVERAGED, COMPOSITE RESULTS OVER 8-MODE TEST, mg/hp-hr

\begin{tabular}{|l|c|c|c|c|}
\hline FUEL TYPE & BASELINE FUEL & $7.7 \%$ ETHANOL & $10 \%$ ETHANOL & $15 \%$ ETHANOL \\
\hline \hline FORMALDEHYDE & 9.16 & 10.50 & 11.04 & 11.78 \\
\hline ACETALDEHYDE & 2.78 & 4.60 & 5.23 & 6.65 \\
\hline ACROLEIN & 1.05 & 1.23 & 0.97 & 1.25 \\
\hline PROPIONALDEHYDE & 0.93 & 0.95 & 1.42 & 1.11 \\
\hline METHYL ETHYL KETONE & 0.12 & 0.15 & 0.13 & 0.12 \\
\hline ETHANOL & 0.36 & 17.11 & 25.12 & 34.51 \\
\hline 1,3-BUTADIENE & 1.16 & 0.21 & 0.56 & 0.74 \\
\hline METHANE & 1.64 & 1.66 & 1.47 & 1.01 \\
\hline BENZENE & 1.13 & 0.57 & 1.01 & 0.98 \\
\hline TOLUENE & 1.09 & 1.20 & 1.65 & 1.60 \\
\hline ETHYLBENZENE & 0.43 & 0.47 & 0.70 & 0.57 \\
\hline m-\& p-XYLENE & 0.89 & 0.74 & 1.12 & 0.73 \\
\hline o-XYLENE & 0.42 & 0.39 & 0.49 & 0.34 \\
\hline HEXANE & 0.03 & 0.20 & 0.27 & 0.15 \\
\hline STYRENE & 0.11 & 0.11 & 0.09 & 0.08 \\
\hline
\end{tabular}

TABLE 15. PAH \& NPAH COMPOUNDS FOR 12.5-L ENGINE, COMPOSITE RESULTS of 8-MODE TEST, ng/hp-hr

\begin{tabular}{||l|c|c|c|c|c|c|c|c||}
\hline FUEL TYPE & \multicolumn{2}{|c|}{ BASELINE FUEL } & \multicolumn{2}{|c|}{$7.7 \%$ ETHANBOL } & \multicolumn{2}{c|}{$10 \%$ ETHANOL } & \multicolumn{2}{c||}{$15 \%$ ETHANOL } \\
\hline COMPOUND/PHASE & $\begin{array}{c}\text { VAPOR } \\
\text { PHASE }\end{array}$ & PM PHAS & $\begin{array}{c}\text { VAPOR } \\
\text { PHASE }\end{array}$ & PM PHASE & $\begin{array}{c}\text { VAPOR } \\
\text { PHASE }\end{array}$ & PM PHAS月 & $\begin{array}{c}\text { VAPOR } \\
\text { PHASE }\end{array}$ & PM PHAS月 \\
\hline Naphthalene & 143664 & 177 & 190188 & 149 & 154824 & 98 & 707495 & 106 \\
\hline Acenaphthylene & 28398 & 91 & 22296 & 64 & 23297 & 56 & 24732 & 35 \\
\hline Acenaphthene & 30382 & 67 & 32291 & 41 & 31932 & 25 & 42270 & 25 \\
\hline Fluorene & 70822 & 269 & 56947 & 184 & 74026 & 151 & 78878 & 105 \\
\hline Phenanthrene & 129464 & 5001 & 107998 & 3246 & 124868 & 2566 & 148862 & 2054 \\
\hline Anthracene & 11327 & 549 & 9195 & 332 & 10309 & 275 & 11839 & 204 \\
\hline Fluoranthene & 2583 & 1940 & 3162 & 1405 & 3225 & 1113 & 4398 & 1021 \\
\hline Pyrene & 4573 & 4278 & 7756 & 4023 & 8929 & 3214 & 11400 & 2775 \\
\hline Benzo(a)anthracene & 18 & 238 & 27 & 368 & 31 & 368 & 66 & 311 \\
\hline Chrysene & 33 & 601 & 56 & 745 & 76 & 713 & 128 & 668 \\
\hline Benzo(b)fluoranthene & 6 & 71 & 5 & 130 & 8 & 122 & 8 & 142 \\
\hline Benzo(k)fluoranthene & 7 & 73 & 4 & 126 & 5 & 130 & 7 & 115 \\
\hline Benzo(a)pyrene & 0 & 51 & 0 & 93 & 2 & 118 & 4 & 75 \\
\hline Indeno(1,2,3-cd)pyrene & 3 & 13 & 0 & 33 & 3 & 40 & 3 & 35 \\
\hline Dibenzo(a,h)anthracene & 0 & 5 & 0 & 6 & 0 & 7 & 0 & 7 \\
\hline 1-Nitropyrene & 6 & 28 & 1 & 18 & 1 & 18 & 1 & 23 \\
\hline \hline
\end{tabular}

\section{DISCUSSION}

Evaluation of ethanol blended fuels in engines with three different fuel injection system designs has yielded the following results. Smoke and particulate matter emissions decreased with increasing ethanol content for all engines and as expected, emissions of acetaldehyde were higher for all engines with increasing ethanol content. The ethanol blended fuels yielded improvements in NOx emissions on the 6.8-L (rotary pump line injector) and 12.5-L (electronic unit injector) engines, but were higher for the 8.1-L engine (high pressure common rail injector. $\mathrm{CO}$ emissions, however, were increased for the 6.8-L and decreased for the other two. Emissions of benzene and 1,3-butadiene were reduced with the ethanol fuels. No clear trends were discernable for the PAH compounds, but 1-nitropyrene was consistently reduced with use of the ethanol blends. Clearly there is potential for further development work.

\section{SUMMARY AND CONCLUSIONS}

This project has generated information on the exhaust emissions effects of various blends of ethanol in diesel fuel. Three concentrations of ethanol in diesel were evaluated on three engines of differing technology and displacement. Three suppliers provided additives for improvement of the characteristics and stability of ethanol blended in diesel fuel. Batches of fuel were prepared at each ethanol concentration with all three additives, 
resulting in a 10-fuel matrix (including reference diesel fuel). The nine alcohol-blended fuels were distributed among the three test engines in a way that each engine experienced operation with each additive and each ethanol concentration.

The engines were operated in duplicate over the 8-mode test procedure described in 40 CFR Part 89 , and over the FTP smoke test. Regulated emissions were reported in brake specific output (mass per unit work). Unregulated emissions, including soluble organic fraction of particulate (SOF), individual hydrocarbons, ethanol, and aldehydes, polynuclear aromatic hydrocarbons (PAH) and 1nitropyrene were reported. All engines with all additive suppliers with all ethanol blends met Tier II regulated emissions requirements.

As expected, increasing ethanol concentration led to higher emissions of acetaldehyde (increases ranging from 27 to 139 percent) and ethanol (from trace levels to levels as high as $52 \mathrm{mg} / \mathrm{hp}-\mathrm{hr}$ ). Smoke and particulate matter emissions decreased with increasing ethanol concentration. PM emissions decreased from 13 to 30 percent. Except on the 6.8-L engine, carbon monoxide emissions also decreased, by up to 15 percent, with increasing ethanol concentration. For the 6.8-L engine, $\mathrm{CO}$ increased by as much as 22.6 percent. $\mathrm{NO}_{\mathrm{x}}$ emissions were reduced with ethanol use on the 6.8-L and 12.5-L engines, with reductions ranging from 5 to 9 percent. Emissions of $\mathrm{NO}_{\mathrm{x}}$ increased by as much as 2 percent on the 8.1-L engine.

Emissions of toxics such as benzene and 1,3-butadiene were reduced with the use of ethanol. Benzene emissions were reduced by up to 50 percent with the ethanol blended fuels. Emissions of 1,3-butadiene were also substantially decreased, ranging from 24 to 82 percent reduction.

Isolated trends were noted for certain PAH compounds. There was a decrease in 1-nitropyrene with use of ethanol in all cases. Particulate phase 1-nitropyrene was reduced from 18 to 62 percent. There was also a general increase in heavy PAH compounds in the particulate phase with ethanol use, and although less pronounced, a general decrease in light PAH compounds in the particulate phase with ethanol use.

\section{ACKNOWLEDGEMENTS}

This work was supported by the National Corn Growers Association and the United States Department of Energy Office of the Biomass Program. John Deere provided the engines. The fuel ethanol was provided by the Illinois Corn Growers Association.

\section{REFERENCES}

1. Peckham, J., "Ethanol-Diesel Raises Saftey, Performance, Health Concerns," Diesel Fuel News, Vol 5, No. 23, pp 9-11, Chemical Week Associates, 2001.
2. Jackson, M. M.. Corkwell, K.C., and DeGroote, C. C., "Study of Diesel and Ethanol Blends Stability," SAE 2003-01-3191, The Society of Automotive Engineers, Warrendale, PA, 2003.

3. Renewable Fuels Association, "Energy Security." http://www.ethanolrfa.org/factfic_ensec.html

4. Corkwell, K.C., and Jackson, $\bar{M}$. M., "Lubricity and Injector Pump Wear Issues with E -Diesel Fuel Blends," SAE 2002-01-2849, Society of Automotive Engineers, Warrendale, PA, 2002.

5. Corkwell, K.C., Jackson, M.M. and Daly, D.T., "Review of Exhaust Emissions of Compression Ignition Engines Operating on E Diesel Fuel Blends," SAE 2003-01-3283, Society of Automotive Engineers, Warrendale, PA, 2003.

6. Walter O. Siegl, Joel F. O. Richert, Trescott E. Jensen, Dennis Schuetzle, Stephen J. Swarin, Jeffrey F. Loo, Arnold Prostak, Don Nagy, Ann M. Schlenker, "Improved Emissions Speciation Methodology for Phase II of the Auto/Oil Air Quality Improvement Research Program--Hydrocarbons and Oxygenates," 930142, Society of Automotive Engineers, Warrendale, PA, 1993

7. Public Law 101-549, "1990 Amendments to the Clean Air Act," November 15, 1990

\section{LIST OF ACRONYMS AND ABBREVIATIONS}

\begin{tabular}{|c|c|}
\hline$\Delta \mathrm{P}$ & Delta $P$ - change in pressure \\
\hline CFR & Code of Federal Regulations, Title 40, Part 89 \\
\hline ASTM & American Society for Testing Materials \\
\hline bhp & brake horsepower \\
\hline C-B & Carbon balance \\
\hline $\mathrm{CO}$ & Carbon Monoxide \\
\hline $\mathrm{CO}_{2}$ & Carbon Dioxide \\
\hline CVS & Constant Volume Sampler \\
\hline DEER & Department of Engine and Emissions Research \\
\hline DNPH & Dinitrophenylhydrazine \\
\hline FTP & Federal Test Procedure \\
\hline$g$ & gram or grams \\
\hline GC-FID & Gas Chromatography-Flame Ionization Detector \\
\hline $\mathrm{HC}$ & Hydrocarbons \\
\hline hp & Horsepower \\
\hline hp-hr & Horsepower-hour \\
\hline HPLC & High Performance Liquid Chromatography \\
\hline ICGA & Illinois Corn Growers Association \\
\hline IHC & Individual hydrocarbons \\
\hline in & Inch or inches \\
\hline $\mathrm{kPa}$ & Kilopascals \\
\hline $\mathrm{kW}$ & Kilowatts \\
\hline L & Liter \\
\hline $\mathrm{lb}-\mathrm{ft}$ & Pound-feet \\
\hline $\mathrm{N}-\mathrm{m}$ & Newton-meters \\
\hline $\mathrm{NO}_{\mathrm{x}}$ & Oxides of Nitrogen \\
\hline NPAH & Nitro Polycyclic Aromatic Hydrocarbons \\
\hline PAH & Polycyclic Aromatic Hydrocarbons \\
\hline PUF & Polyurethane foam \\
\hline PUF/XA & AD-2 PUF sandwiched with XAD-2 resin \\
\hline rpm & Revolutions per minute \\
\hline SOF & Soluble organic fraction \\
\hline
\end{tabular}


APPENDIX A FUEL PROPERTIES

ANALYTICAL RESULTS FOR ETHANOL STOCK

\begin{tabular}{|c|c|c|c|c|}
\hline Test Parameter & Test Method & Units & Tank 22 & Tank 23 \\
\hline$\overline{\mathrm{API}} @$ @ 60 $\mathrm{F}$ & \multirow{3}{*}{ D4052 } & none & 47.6 & 47.6 \\
\hline Specific Gravity @ 60 $\mathrm{F}$ & & none & 0.7901 & 0.7901 \\
\hline Density @ $15^{\circ} \mathrm{C}$ & & grams/L & 789.7 & 789.7 \\
\hline \multirow{2}{*}{ Ethanol content } & \multirow{2}{*}{ D5501 } & weight percent & 96.1 & 95.8 \\
\hline & & volume percent & 95.6 & 95.3 \\
\hline Water content & D6304 & percent & 0.548 & 0.548 \\
\hline
\end{tabular}

Characterizations of the test fuels are presented in the following table. One should bear in mind that the ASTM methods are not necessarily designed to accommodate a fuel such as an ethanol-diesel blend. Ethanol is suspended in an emulsion by virtue of the co-solvents and other substances in the various additive packages.
EM-4895- $F$ is the internal designation of the on-highway diesel (nominal $400 \mathrm{ppm}$ sulfur) used in preparing the ethanol blends. The remaining EM- codes are the internal identification codes used in our fuel handling, storage, and inventory system. Another batch of low-sulfur certification diesel, with essentially the same properties was used in the baseline emissions measurements of the engines, designated EM-4970-F.

TEST FUEL CHARACTERISTICS

\begin{tabular}{|c|c|c|c|c|c|c|c|c|c|c|c|}
\hline Test Parameter & $\begin{array}{l}\text { ASTM } \\
\text { Test } \\
\text { Method }\end{array}$ & \begin{tabular}{|c|} 
EM-4895-F \\
BaseBlend \\
Stock
\end{tabular} & \begin{tabular}{|c|} 
EM- $4929-\mathrm{F}$ \\
$7.7 \% \mathrm{EtOH}$ \\
$\mathrm{A}$
\end{tabular} & $\begin{array}{c}\text { EM-4930-F } \\
7.7 \% \text { EtOH } \\
\text { B }\end{array}$ & $\begin{array}{c}\text { EM- }-4932-\mathrm{F} \\
7.7 \% \text { EtOH } \\
C\end{array}$ & \begin{tabular}{|c|} 
EM- $4935-\mathrm{F}$ \\
$10 \%$ EtOH \\
$\mathrm{A}$
\end{tabular} & $\begin{array}{c}\text { EM-4936-F } \\
10 \% \text { EtOH } \\
\text { B }\end{array}$ & \begin{tabular}{|c|} 
EM-4937-F \\
$10 \%$ EtOH \\
$C$ \\
\end{tabular} & $\begin{array}{c}\text { EM-4949-F } \\
15 \% \text { EtOH } \\
\text { A }\end{array}$ & $\begin{array}{c}\text { EM-4950-F } \\
15 \% \text { EtOH } \\
\text { B }\end{array}$ & $\begin{array}{c}\text { EM-4951-F } \\
15 \% \text { EtOH } \\
C\end{array}$ \\
\hline Copper Corrosion & D-130 & $1 \mathrm{~B}$ & $\overline{1 \mathrm{~B}}$ & $1 \mathrm{~B}$ & $1 \mathrm{~B}$ & $1 \mathrm{~B}$ & $1 \mathrm{~B}$ & $1 \mathrm{~B}$ & $1 \mathrm{~B}$ & $1 \mathrm{~B}$ & $1 \mathrm{~B}$ \\
\hline Cloud Point, ${ }^{\circ} \mathrm{C}$ & $\mathrm{D}-2500$ & -20 & 8 & 8 & 5 & 10 & 12 & -6 & 15 & 18 & -7 \\
\hline Water and Sediment, $\mathrm{mL}$ & $\mathrm{D}-2709$ & 0.01 & 0.01 & 0.01 & 0.01 & 0.01 & 0.01 & 0.01 & 0.01 & 0.01 & 0.01 \\
\hline Viscosity @ $40^{\circ} \mathrm{C}, \mathrm{cSt}$ & D-445 & 2.376 & 2.127 & 2.110 & 2.140 & 2.015 & 2.093 & 2.062 & 1.964 & 1.962 & 2.120 \\
\hline Ash Content, mass \% & D-482 & $<0.001$ & $<0.001$ & $<0.001$ & $<0.001$ & $<0.001$ & $<0.001$ & $<0.001$ & $<0.001$ & $<0.001$ & $<0.001$ \\
\hline $\begin{array}{l}\text { Carbon Residue (10\% } \\
\text { Bottom), mass } \%\end{array}$ & D-524 & 0.11 & 0.09 & 0.14 & 0.26 & 0.13 & 0.15 & 0.12 & 0.13 & 0.18 & 0.21 \\
\hline Cetane Number & D-613 & 47.4 & 48.6 & 49.9 & 49.1 & 46.6 & 47.5 & 46.9 & 47.3 & 47.6 & \begin{tabular}{c|c|}
47.4 \\
\end{tabular} \\
\hline Flash Point, ${ }^{\circ} \mathrm{C}$ & D-93 & 63.3 & 13.9 & 10.0 & 13.9 & 12.2 & 10.6 & 10.6 & 9.4 & 11.1 & 9.4 \\
\hline HFRR, Wear Scar, mm & $\mathrm{D}-6079$ & 0.525 & 0.280 & 0.320 & 0.410 & 0.240 & 0.280 & 0.405 & 0.295 & 0.335 & 0.410 \\
\hline BOCLE, Scuffing Load, $\mathrm{g}$ & $\mathrm{D}-6078$ & 3800 & 5350 & 4350 & 4200 & 6500 & 5750 & 3550 & 3850 & 6050 & 4400 \\
\hline $\begin{array}{l}\text { Density, g/L } \\
\text { Specific Gravity } \\
\text { API }\end{array}$ & D-4052 & $\begin{array}{r}839.9 \\
0.8405 \\
36.9\end{array}$ & $\begin{array}{r}835.9 \\
0.8364 \\
37.7\end{array}$ & $\begin{array}{r}836.8 \\
0.8373 \\
37.5\end{array}$ & $\begin{array}{r}835.4 \\
0.8359 \\
37.8\end{array}$ & \begin{tabular}{r|}
835.0 \\
0.8355 \\
37.9
\end{tabular} & $\begin{array}{r}837.0 \\
0.8375 \\
375\end{array}$ & $\begin{array}{r}834.3 \\
0.8348 \\
380\end{array}$ & $\begin{array}{r}833.0 \\
0.8336 \\
383\end{array}$ & \begin{tabular}{r|}
835.2 \\
0.8358 \\
378
\end{tabular} & $\begin{array}{r}832.1 \\
0.8326 \\
205\end{array}$ \\
\hline Carbon, mass \% & D-5291 & $\begin{array}{r}36.9 \\
86.85\end{array}$ & $\begin{array}{r}37.7 \\
84.29\end{array}$ & $\begin{array}{r}37.5 \\
83.90\end{array}$ & $\begin{array}{r}37.8 \\
84.38\end{array}$ & $\begin{array}{r}37.9 \\
84.23\end{array}$ & $\begin{array}{r}37.5 \\
83.78\end{array}$ & $\begin{array}{r}38.0 \\
83.12\end{array}$ & $\begin{array}{r}38.3 \\
82.67\end{array}$ & $\begin{array}{r}37.8 \\
83.13\end{array}$ & $\begin{array}{r}38.5 \\
81.13\end{array}$ \\
\hline Hydrogen, mass \% & & 13.11 & 13.08 & 13.08 & 12.99 & 13.26 & 13.12 & 13.28 & 13.13 & 13.02 & 12.99 \\
\hline $\begin{array}{l}\text { Oxygen, mass } \% \text { by } \\
\text { difference }\end{array}$ & & 0.04 & 2.63 & 3.02 & 2.63 & 2.51 & 3.10 & 3.6 & 4.20 & 3.85 & 5.88 \\
\hline Distillation, ${ }^{\circ} \mathrm{C}$ & $\mathrm{D}-86$ & & & & & & & & & & \\
\hline & & $\begin{array}{l}180.1 \\
195.1\end{array}$ & $\begin{array}{l}73.4 \\
78.6\end{array}$ & $\begin{array}{l}75.1 \\
78.7\end{array}$ & $\begin{array}{l}68.1 \\
76.5\end{array}$ & $\begin{array}{l}60.7 \\
74.7\end{array}$ & $\begin{array}{l}68.8 \\
77.9\end{array}$ & $\begin{array}{l}78.2 \\
79.2\end{array}$ & $\begin{array}{l}65.3 \\
75.6\end{array}$ & $\begin{array}{l}77.3 \\
77.8\end{array}$ & $\begin{array}{l}61.9 \\
78.5\end{array}$ \\
\hline $10 \%$ & & 208.5 & 109.7 & 154.2 & 79.8 & 80.2 & 79.6 & 78.1 & 78.3 & 78.1 & 78.7 \\
\hline $15 \%$ & & 217.1 & 197.7 & 200.9 & 179.8 & 80.7 & 133.3 & 117.3 & 81.6 & 107.2 & 81.1 \\
\hline $20 \%$ & & 224.9 & 213.3 & 212.3 & 205.5 & 145.7 & 205.2 & 202.2 & 110.1 & 194.3 & 167.7 \\
\hline $30 \%$ & & 238.6 & 230.2 & 229.2 & 220.7 & 212.1 & 223.7 & 220.9 & 213.4 & 219.9 & 216.7 \\
\hline $40 \%$ & & 249.2 & 243.4 & 242.5 & 238.7 & 233.5 & 238.1 & 235.0 & 232.0 & 234.4 & 234.7 \\
\hline $50 \%$ & & 258.8 & 254.5 & 252.6 & 250.6 & 247.2 & 249.7 & 247.0 & 246.6 & 246.3 & 249.1 \\
\hline $60 \%$ & & 268.0 & 264.8 & 263.3 & 260.8 & 259.3 & 260.3 & 257.3 & 258.0 & 257.2 & 260.3 \\
\hline $70 \%$ & & 278.3 & 275.4 & 274.6 & 272.0 & 270.6 & 271.3 & 269.4 & 269.2 & 268.7 & 272.1 \\
\hline $80 \%$ & & 290.6 & 288.4 & 288.6 & 285.6 & 284.3 & 284.6 & 282.7 & 281.7 & 282.8 & 285.1 \\
\hline $90 \%$ & & 307.7 & 306.1 & 307.6 & 305.4 & 303.4 & 302.3 & 300.8 & 299.2 & 303.8 & 303.9 \\
\hline $95 \%$ & & 322.0 & 322.2 & 321.4 & 317.8 & 320.4 & 315.2 & 314.9 & 310.9 & 315.7 & 319.8 \\
\hline FBP & & 335.9 & 335.0 & 326.9 & 331.7 & 332.3 & 334.4 & 330.2 & 332.7 & 324.6 & 333.4 \\
\hline Recove & & 98.2 & 98 & 95.6 & 95 & 97.5 & 96.1 & 96.4 & 95.4 & 96.1 & 97.9 \\
\hline Loss, mL & & 1.3 & 1.5 & 1.2 & 3.8 & 1.4 & 2.9 & 2.7 & 3.2 & 2.9 & 1 \\
\hline Residue, $\mathrm{mL}$ & & 0.5 & 0.5 & 3.2 & 1.2 & 1.1 & 1 & 0.9 & 1.4 & 1 & 1.1 \\
\hline
\end{tabular}

